exchange of information, etc., and exceptions are made for special circumstances such as saving life at sea, damage to ships and so on.

The convention will come into force twelve months after the date on which no less than ten Governments have adhered, including five Governments each with not less than 500,000 gross tanker tonnage. In addition to the convention, the conference adopted. eight resolutions which are submitted to the Governments and other bodies concerned for consideration and appropriate action, which included a recommendation that a further conference to review the matter in the light of experience of the working arrangements recommended by the conference should be held within three years.

\section{The Mammal Society of the British Isles}

The study of British mammals has undoubtedly been handicapped by the lack of a national scientific society devoted to the subject. At a conference held at the University of Birmingham during April 23-26, the appropriate organization, to be known as the Mammal Society of the British Isles, was brought into being, and the first officers and provisional committee were elected. In welcoming those present, S. Zuckerman emphasized the reciprocity of field and laboratory studies and stated that the Society would be of considerable value to experimentalists as well as to naturalists. This theme was developed in the opening paper by Alastair N. Worden on "The Study of Mammals", in which the need for codifying knowledge and the interest of mammalogy to those engaged in agriculture, forestry, conservation, pest control, veterinary science and human medicine were also discussed. It was suggested that a work devoted to mammals on the British list, comparable in status to the "Handbook of British Birds", although not necessarily modelled on similar lines, would fulfil an important gap and might be prepared on behalf of the Society as knowledge permitted. Other papers presented at the conference were on the trapping of small mammals (H. N. Southern), bats (M. Blackmore and J. H. D. Hooper), shrews (Peter Crowcroft), seals (R. M. Lockley), badgers (E. G. Neal and H. R. Hewer) and the work of the Merelewood Research Station, Nature Conservancy, by its director, K. R. S. Morris.

The following were elected officers of the Society : President, the Earl of Cranbrook; Chairman, A. N. Worden; Hon. Secretary of the Scientific Advisory Committee, H. N. Southern ; Hon. Treasurer, H. G. Hurrell ; Hon. Secretary, T. J. Pickvance, Department of Extra Mural Studies, University of Birmingham, Edmund Street, Birmingham, 3. The remaining members nominated to form the provisional committee were: K. R. S. Morris, H. V. Thompson, Peter Crowcroft, R. M. Lockley, M. Blackmore. The annual subscription has been fixed at one guines, and further details can be obtained on application to the Hon. Secretary at the address given.

\section{Vitamin Standards for Margarine}

Acrrng on the advice of the Food Standards Committee, the Minister of Food, Major the Right Hon. Gwilym Lloyd-George, has made the Food Standards (Margarine) Order, which requires that Vitamins A and $\mathrm{D}$ shall continue to be added to all margarine sold by retail. The Order, which came into force on May 16, prescribes that margarine shall contain between 760 and 940 international units of vitamin $A$ per ounce and between 80 and 100 international units of vitamin D per ounce. This vitamin A content is roughly equivalent to that of butter. The required vitamin $\mathbf{D}$ content remains the same (apart from a tolerance of 10 per cent) as under control. The Order prescribes the method of analysis to be used for determining the vitamin A content of margarine. In view of the difficulties involved in the estimation of vitamin $D$ in margarine, it has been agreed with the manufacturers that they will add the vitamins in the form of a 'master mix'. A master mix should consist, of an edible vegetable oil containing either vitamin A and vitamin $D$, or provitamin $A$ and vitamin $D$. The manufacturers of vitamins in Britain have agreed to produce master mixes for this purpose containing vitamins $A$ and $D$ in the ratio of $940: 100$. Provided this ratio is observed, manufacturers are free to vary the composition of each master mix and the directions for its use according to the requirements of the margarine manufacturer. Any edible vegetable oil may be used as a diluent.

\section{Energy Resources of Great Britain}

IN his presidential address delivered on April 8 to the Institute of Fuel, entitled "Energy for Britainthe Decades Ahead", Dr. Idris Jones has ventured a prophetic role in his comprehensive review of the trends in the development and use of fuel and energy from which the possibilities of the future may be envisaged. Coal is the primary source of energy in Great Britain ; $25 \times 10^{8}$ tons have been mined up to now, and reserves of barely twice this amount still remain. Deposits of peat in the whole country are equivalent only to twenty years of coal production. For oil fuel, Britain will have to continue to rely on overseas supplies, and the duration of such supply may amount to another hundred years. The future production of thermal-electric power from coal may be generated at an efficiency of 37 per cent in large units of several hundred megawatts capacity. Complete electrification will be a feature of future coal-mining, which will be just as importent in A.D. 2000 as it is to-day. Though the potentialities of generating hydro-electric power in Britain are small, interconnexion of power supplies between Britain and the Continent of Europe would be favourable. Of the other sources in Britain, windpower is being investigated seriously, solar energy offers little at present, but heat pumps may do so. A new form of 'fuel' cell, using strontium-90, a fission product in an atomic pile, is now being developed, and nuclear energy should come to the rescue of disappearing coal reserves. Finally, a valuable detailed review is given by Dr. Jones of the probable future increases in fuel-burning efficiency during the next fifty years, whereby the current figure of about 35 per cent may increase to $45-50$ per cent.

\section{Bananas}

For many years species of seemingly close affinity with the banana had all been classified within the genus Musa. For some of the species, however, the genus Ensete had been proposed in 1862. This received little recognition until E. E. Cheesman (Kew Bull., No. 97 ; 1947) pointed out that its members differed from the true bananas in being mainly African in distribution, in being monocarpic, in having a basic chromosome number different from bananas, and in the large size of their seeds. The true bananas are generally held to be of Indo-Malaysian origin. 